\author{
Grzegorz Olszyna \\ dr inż. \\ AGH Akademia Górniczo-Hutnicza, \\ Katedra Transportu Linowego \\ olszyna@agh.edu.pl

\section{Tomasz Rokita} \\ dr inż. \\ AGH Akademia Górniczo-Hutnicza, \\ Katedra Transportu Linowego \\ rokitom@agh.edu.pl

\section{Marian Wójcik} \\ dr hab. inż., prof. AGH \\ AGH Akademia Górniczo-Hutnicza, \\ Katedra Transportu Linowego \\ marianw@agh.edu.pl
}

DOI: 10.35117/A_ENG_17_03_05

\title{
Have bicable aerial ropways got a future?
}

Summary: The article contains a historical review of the origin and development bicable aerial ropeways. Describes the pros and cons of the ropeway system in comparison with the monocable aerial ropeways. The later in the article presents a discussion on the conditionality bicable aerial ropeway construction in Poland. The analysis included all four currently operated in Poland bicable aerial ropeways. We attempt to answer the question whether the bicable system is the optimal solution for those aerial ropeways. The article concerns the problem of research and evaluation of the results of these

Keywords: monocable aerial ropeways, bicable aerial ropeways, rope transport.

\section{Introduction}

The inspiration for writing this article was published in the ISR (Internationale Seilbahn Rundschau) in the year 2015, an article on the meaning of the construction of the bicable ropeways by R. Gric and J. Nejeza [3]. The article did not give an unambiguous answer as to what is going on with such systems. In this article, the authors set themselves the purpose of analyzing and evaluating the application of the bicable system in ropeways operating in Poland, trying to answer the question whether the construction of bicable ropeways still makes sense.

\section{Origins and development of the bicable system}

Bicable overhead cableways are one of the oldest cable systems and have been used for more than 144 years. Since then, monocable system has become more widely distributed, which is constantly being enriched by new construction solutions by leading manufacturers. First of all, a monocable system is usually less complicated and less expensive. Today, ropes are commonly 
associated with mountain tourism, and especially with skiing. Few people realize that the domination of passenger trains began only after World War II. It lasts until today. More than $99 \%$ of the cableways are railways for passenger transport. However, it is worth noting that the development of this type of equipment was initiated by freight cableways.

In 1872, the 28-year-old Saxon engineer Adolf Bleichert, together with Eng. Theodore Otto constructed their first cableway for the paraffin factory. The system and the invention of the Bleichert line consisted of two ropes, one of which was larger and heavier, and was the driving track of the goods carrying trucks; the second one is much thinner and lighter than the rope that drives these carts [12]. A very important improvement was the introduction of heavy-duty loadcarrying rope and a monocable tensioning rope system. Based on the mentioned prototype, in May 1874 both partners launched a cableway for coal transport in Teutschenthal near Halle, and on 1 July opened the company Bleichert \& Otto and patented their technical solutions. Over time, the company expanded, became more successful and became a global leader and a major driver of technical progress in the field of bicable freight and passenger transport. By the early 1940s, Bleichert had built around 4,000 cableways around the world. A large part of this group of railways to relatively short railways for loading ships or railways for the military to build fortifications. During the First World War, the company supplied the German army with hundreds of mobile cableways. After World War II under the so-called, the company's war reparations were partially exported to the USSR, and most of the engineering personnel entered the Federal Republic of Germany. The construction of the cable ropeway has disappeared from both parts of Germany but was soon reborn in Austria [1].

Previously, bicable overhead aerial ropeways were often referred to as the German cableways to distinguish them from the monocable railway also developed during that period, which were called the English system, and were invented by an Englishman named Hodgson. The longest ropeway in the world is a $96 \mathrm{~km}$ long consisting of eight sections, also an overhead bicable lift for material transport. It was opened in Sweden in 1943 for the transport of ore from the Kristinebergsgruvan mine, which is now owned by Boliden AB (Swedish mining company) to the Skelleftea port. By the time of its closure in 1987, this industrial ropeway transported 12 million tons of ore (copper, lead, zinc, silver, and gold annually). The fourth stretch from Ortrask to Menstrask, which is $13.2 \mathrm{~km}$ long, was converted to passenger service for the travel industry.

With the emergence of heavy trucks and other means of transport, such as conveyor belts, overhead bicable rails have lost importance for the transportation of loose materials, and only a portion of these installations continue to operate. Railways for passenger transport were initially a small part of the total rail population. They were, however, attracting tourists, usually built in high mountains or rivers. By the 1990s there were at least a dozen manufacturers of this type of ropeway [4]. Worth mentioning manufacturers are: Von Roll, Waagner-Biró, Chrudim Transport, Girak, POMA and others. In the following years, the merger process began, and as a result, there are now such groups as Doppelamyr-Garaventa, Leitner-POMA and much smaller Bartholet.

\section{Comparison of bicable and monocable systems}

Compared to monocable, bicable with a separate rope and drive can be designed from much longer rope spans and can, therefore, be built in difficult terrain where monocable cannot be used. In the case of the bicable, the position of the rope under the rope produces a favorable 
moment of restoring the vehicle's position in the case of lateral swing [8]. This explains their better stability compared to the monocables for the lateral ones. The lower drag forces in the system and the relatively small mass displaced in the direction of travel reduce the circumferential force of the drive, and thus the energy costs. The major disadvantage of the bicable rope system compared to the monocable ropeway is the much higher capital expenditure for the same capacity. Also, especially where only one or a small group of vehicles is in the rope spine, the bicable ropeway can have a problem with the rope tension. In some older installations, additional lifting support was used to provide sufficient voltage for the empty rope [1].

The following summarizes the major drawbacks and advantages bicable ropeway (default with respect to the system monocable ropeway.)

Advantages of bicable ropeways:

- No limit to the height of the cab above the ground,

- Resistance to wind,

- Large lifting capacity (large cabin capacity)

- Low power requirements,

Disadvantages:

- Large investment costs,

- Greater than in the case of monocable ropeways, the complexity of the rail system,

- More extensive construction of road supports,

- Typically lower capacity

\section{Bicable ropeways in poland}

\section{$R W$ Kasprowy Wierch in Zakopane}

The ropeway to Kasprowy Wierch was the first such investment in Poland, and the sixtieth in the world (Figures 1 and 2). The ropeway to Kasprowy Wierch is actually two independent aerial bicable circular ropeways that transport the skiers and passengers in the cabins. In the section "Kuźnice-Myślenickie Turnie", the traffic is between the lower stations (Kuźnice) and the upper (Myślenickie Turnie). Upper station - Myślenickie Turnie is also an intermediate station, allowing tourists to change to the second section of the railway to Kasprowy Wierch.

In the second section of the ropeway "Myślenic Turnie - Kasprowy Wierch" the traffic is between the lower stations (Myślenickie Turnie) and the upper part (Kasprowy Wierch).In each stretch, two carriages were suspended on one support line - one moving up and one down. Each car could carry 30 passengers. The work was completed on February 29, 1936, and the first passengers entered Kasprowy Wierch on March 15, 1936. In 1961, the ropeway was modernized, by replacing the wagons with new ones. 


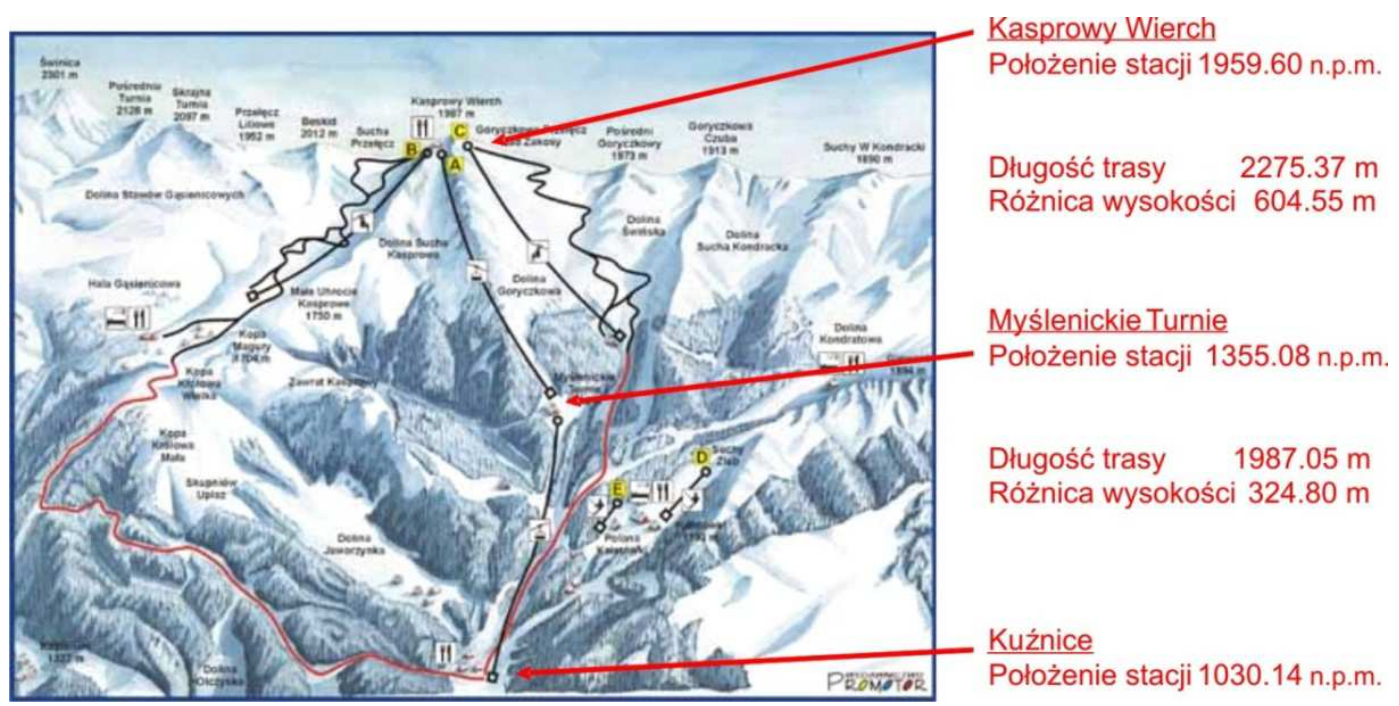

1. Route of the ropeway to Kasprowy Wierch

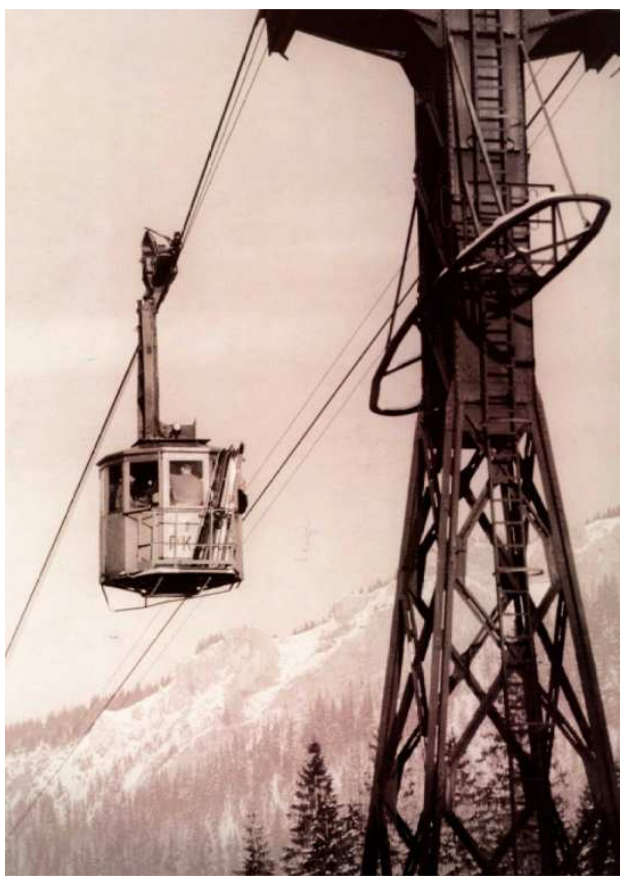

2. View of the original ropeway from 1936 


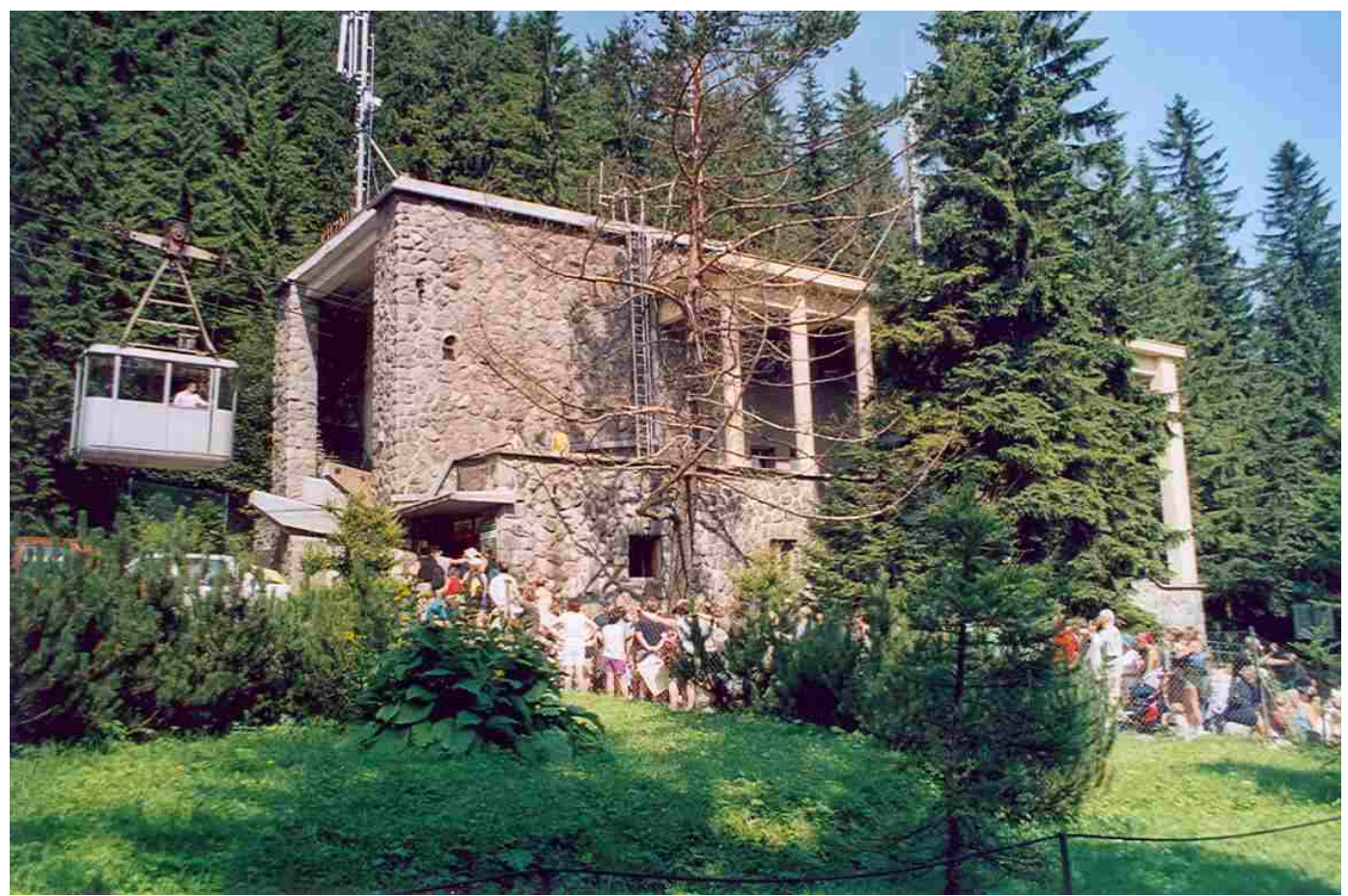

3. View of the lower ropeway station (Kuźnice) before modernization in 2007

Only seventy years later, a thorough modernization of this ropeway began. Basic modernization assumptions are:

- - maintenance of the bicable shuttle system,

- - the use of existing building station substances,

- carriages with wagon brakes,

- - double ropes,

- - use of constant tensioning of ropes,

- $\quad$ - sliding platforms

- - comfortable cabin for 60 people with safety glass,

- - asynchronous motor with frequency inverter,

- - new supports with the inclusion of existing foundations,

- $\quad$ - rescue winch in section 2.

The drives of both ropeways sections are located in the Myślenice Turnie station. The engine room is below the platform level. At each station, there are drums for fixing ropes.To ensure safe and comfortable climbing and descent from cabs, there are mobile landing platforms in each station. These platforms move in a direction perpendicular to the railroad route depending on which of the cabs is approaching the station. Now the cabins look like fig. 4.

On the route of each section of the ropeway, there are 3 steel supports with a truss structure bolted to the foundations [6]. The current parameters of Kasprowy Wierch are summarized in the table 4.1. 
Tab. 1. List of basic parameters KL Kasprowy Wierch

\begin{tabular}{|c|c|c|}
\hline Parameter & Section I & Section II \\
\hline Manufacturer & \multicolumn{2}{|c|}{$\begin{array}{c}\text { Garaventa Switzerland } \\
\text { (Doppelmayr Group) }\end{array}$} \\
\hline Type & \multicolumn{2}{|c|}{$\begin{array}{c}\text { 60-ATW (bicable with swing } \\
\text { motion with } 60 \text {-person } \\
\text { cabins) }\end{array}$} \\
\hline Length of the railroad tracks horizontally & $1959.75 \mathrm{~m}$ & $2192.00 \mathrm{~m}$ \\
\hline Difference in height of railroad platforms & $324.80 \mathrm{~m}$ & $604.55 \mathrm{~m}$ \\
\hline Route length on the hillside & $1987.05 \mathrm{~m}$ & $2275.37 \mathrm{~m}$ \\
\hline Number of ropes (in each course) & \multicolumn{2}{|c|}{2 pieces } \\
\hline Number of supports on the route & \multicolumn{2}{|c|}{3 pieces } \\
\hline Number of cabins on each section & \multicolumn{2}{|c|}{2 pieces } \\
\hline Cabin capacity & \multicolumn{2}{|c|}{60 people } \\
\hline Transport capacity & \multicolumn{2}{|c|}{$\begin{array}{l}180 \text { people/h (summer) } \\
360 \text { people/h (winter) }\end{array}$} \\
\hline \multirow[t]{2}{*}{ Driving speed: } & $7.0 \mathrm{~m} / \mathrm{s}$ & $8.0 \mathrm{~m} / \mathrm{s}$ \\
\hline & $5.5 \mathrm{~m} / \mathrm{s}$ & $6.0 \mathrm{~m} / \mathrm{s}$ \\
\hline The drive ropeway station & $\begin{array}{c}\text { in the upper } \\
\text { station }\end{array}$ & $\begin{array}{c}\text { in the lower } \\
\text { station }\end{array}$ \\
\hline Tensioning station for the drive rope & $\begin{array}{l}\text { in the upper } \\
\text { station }\end{array}$ & $\begin{array}{l}\text { in the upper } \\
\text { station }\end{array}$ \\
\hline
\end{tabular}

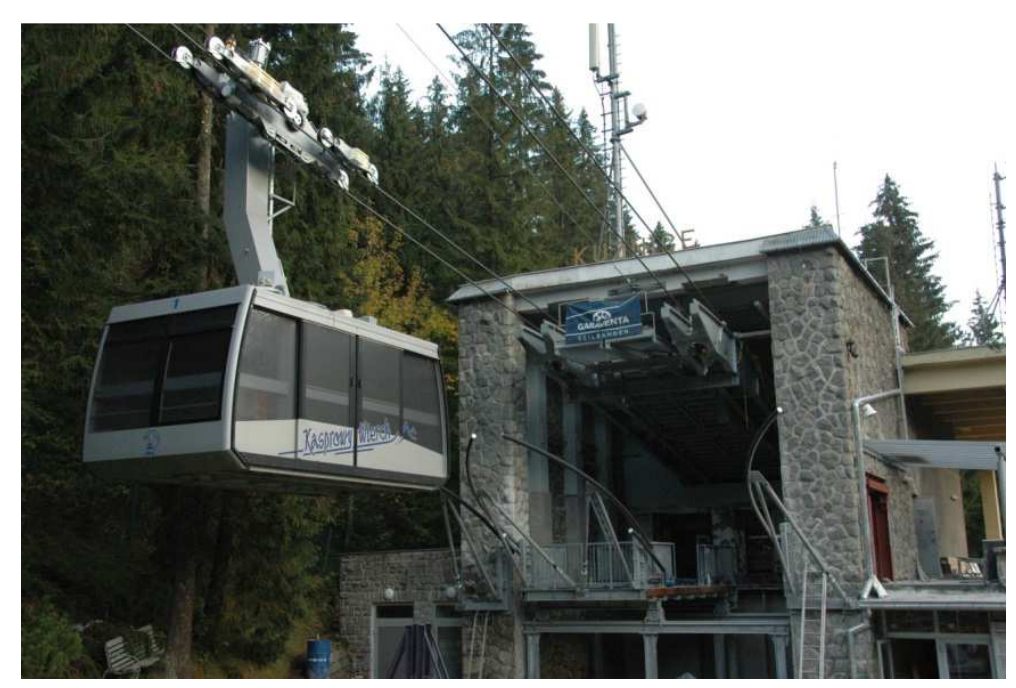

4. 60 passenger cabin on the section I - lower station Kuźnice.

Why was bicable system used? The basic premises for the use of the bicable system were in this case the following conditions:

- required high resistance to lateral gusts of wind,

- maximum limit of number of supports on the route (3 supports on each section), 
- $\quad$ high cab height above the ground (even about $150 \mathrm{~m}$ - in the second section),

- preferred swing motion, due to capacity limitation,

- lack of space for unpowered ropeway stations.

The above conditions clearly indicate that the optimal solution in this case is the bicable ropeway $[2],[10],[11]$.

\section{$R W$ Polinka in Wrocław}

After 2010, an idea was created to build a ropeway through the Oder River in Wroclaw near the Wroclaw University of Technology. Various types of overhead ropeways were considered. Finally, it was decided to use a bicable (with one rope carrier) with a swing motion. The main advantages of the adopted concept are as follows:

- no collision with objects and transport routes of the city of Wroclaw,

- fully ecological transport system - electric drive, practically no noise,

- this type of rail transports people in cabins irrespective of the weather (only the wind at speeds above $15 \mathrm{~m} / \mathrm{s}$ will cause the need to immobilize the ropeway).

The construction of the ropeway began on April 25, 2013 and was launched on October 1 of the same year. Table 2 summarizes the basic parameters of RW Polina. Figure 5 shows the route of RW Polinka on the Oder.

Tab.2. Summary of basic RW Polina parameters

\begin{tabular}{|l|l|}
\hline \multicolumn{1}{|c|}{ Parameter } & \multicolumn{1}{|c|}{ Doppelmayr Group } \\
\hline Manufacturer & $\begin{array}{l}\text { 15-ATW (bicable with swing } \\
\text { motion) }\end{array}$ \\
\hline Type & with 15-person cabins \\
\hline Length of the railroad tracks horizontally & $373 \mathrm{~m}$ \\
\hline Difference in height of railroad platforms & \\
\hline Route length on the hillside & 1 piece \\
\hline Number of ropes (in each course) & 2 pieces \\
\hline Number of supports on the route & $22.00 \mathrm{~m}$ and $19.12 \mathrm{~m}$ \\
\hline Number of cabins on each section & $268 \mathrm{~m}$ \\
\hline Cabin capacity & 2 pieces \\
\hline Transport capacity & 15 people \\
\hline Driving speed: & 366 people / h (summer) \\
\hline & $5.0 \mathrm{~m} / \mathrm{s}$ \\
\hline The drive ropeway station & $\begin{array}{l}\text { On the coast of the } \\
\text { Wyspiański }\end{array}$ \\
\hline Tensioning station for the drive rope &
\end{tabular}




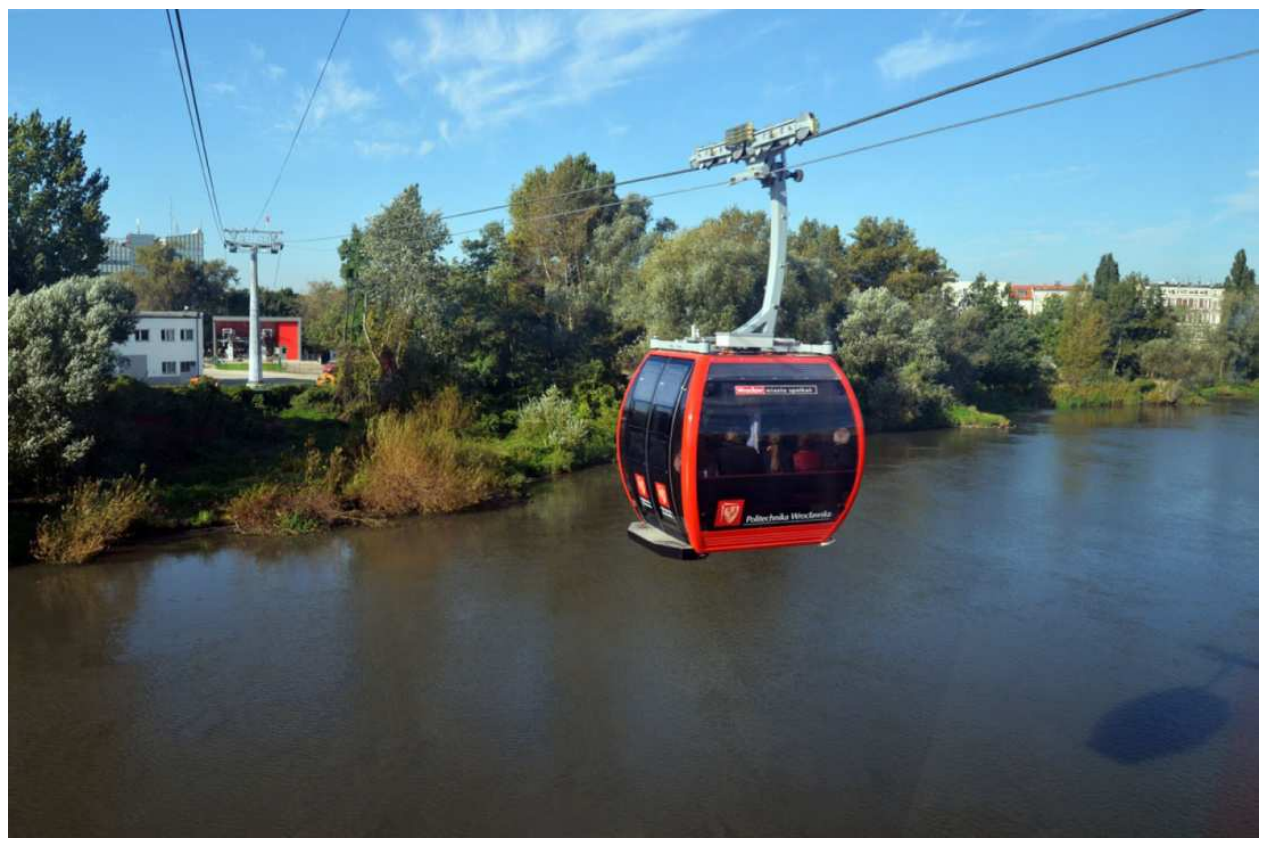

5. Route of RW Polinka above the Oder.

Why was bicable system used? The basic premises for the use of thebicable system were in this case the following conditions:

- high wind resistance,

- obstacle (Oder river) which imposes a large distance between the supports;

- ropeway route (gauge of streets, distance from floating objects - icable ropeway offers more possibilities, e.g. large slope angles);

- evacuation (the water tank is not possible to evacuate down from the cabin, the bicable rpeways offers more opportunities to evacuate along the rope);

- difficulties in the construction of the ropeway station due to limited space for these facilities.

However, there are several aspects that speak against this solution. They can be counted as i.a.:

- - no capacity to increase capacity (if needed);

- - the height of the route over the terrain would also be possible for the monocable ropeway (elgl unshackled with two groups of cabins),

The above conditions indicate that a good solution in this case is the bicable ropeway, although the use of monocable ropeway would be also possible in this case.

\section{RW janikowo-piechcin}

Janikowo-Piechcin cableway is a classic bicable ropeway. It was commissioned in 1960 and merged the limestone mine in Piechcin with two soda plants in Janikowo and in Mysłowice. From the plant in Piechcin the ropeway goes straight to the cut-off station at Zakłady w Janikowie. Along the way, it passes over Lake Pakoski (Figure 4.6). After passing through the station, the line turns away from the straight line by about 30 o and reaches the Janików Plant. In the past, the angular station was a docking station, also docked with wagons to the Matew. The 
section to Mątew passed over the Inowroclaw-Poznan opeway line and the Piotrowickie Lake. At the height of the village of Krusza there was an angular station and after a change of direction by 450 the ropeway ran to Zakłady w Mątwach. The section of Piechcin-Janikowo has a length of about $7.4 \mathrm{~m}$ and none of the Mątew has a length of about $12 \mathrm{~km}$. The track is divided into 6 sections (fig. 6), at the ends of which are anchoring, anchoring or tensioning - anchoring stations (fig. 7). Single sections of ropes on one side are anchored in the stations, and on the other, they are anchored to the joints with the tensioning ropes [9]. At the ends of the tension ropes, there are baskets with tensioning weights. There are 7 to 12 supports in each section. The ropeway works in continuous motion, providing approximately 125 tons of limestone within an hour.

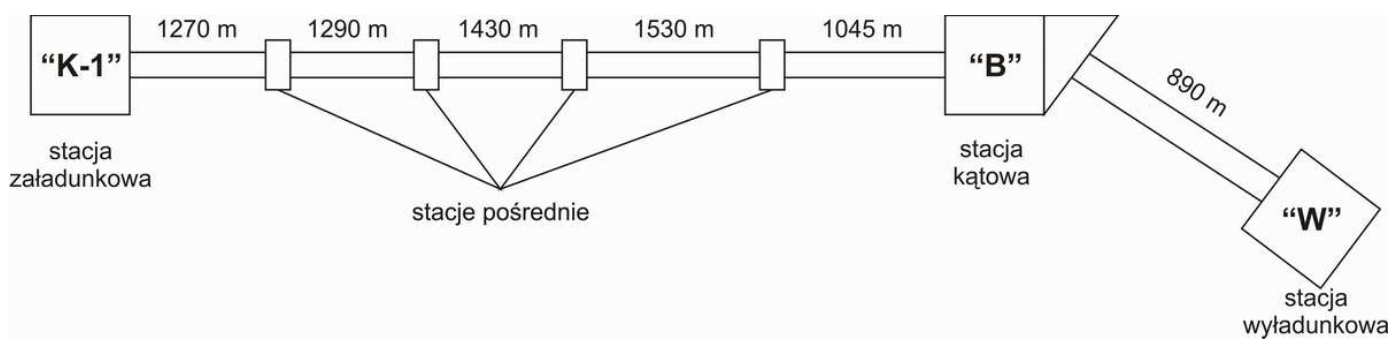

6. Scheme of the freight ropeway Janikowo - Piechcin [5]

The basic technical specifications of the ropeway are:

- $\quad$ speed of carriages $\mathrm{v}=2.3 \mathrm{~m} / \mathrm{s}$

- Propulsion rope $\phi 24$ with a mass of $2.12 \mathrm{~kg} / \mathrm{m}$, length about $14800 \mathrm{~m}$

- - number of vehicles: 82 full wagons with a total weight of about $2100 \mathrm{~kg}$ each and 82 empty ones with a weight of $693 \mathrm{~kg}$ each

- $\quad$ - Average distance between vehicles approx. $92 \mathrm{~m}$ (approx. $40 \mathrm{~s}$ )

- $\quad$ - the number of supports on the railway line is 60 pieces

- $\quad$ - the nominal power of the rail propulsion engine is 75 .

Figure 7 shows the ropeway route, and in Figure 8, one of the stations that fastens the hang sling.

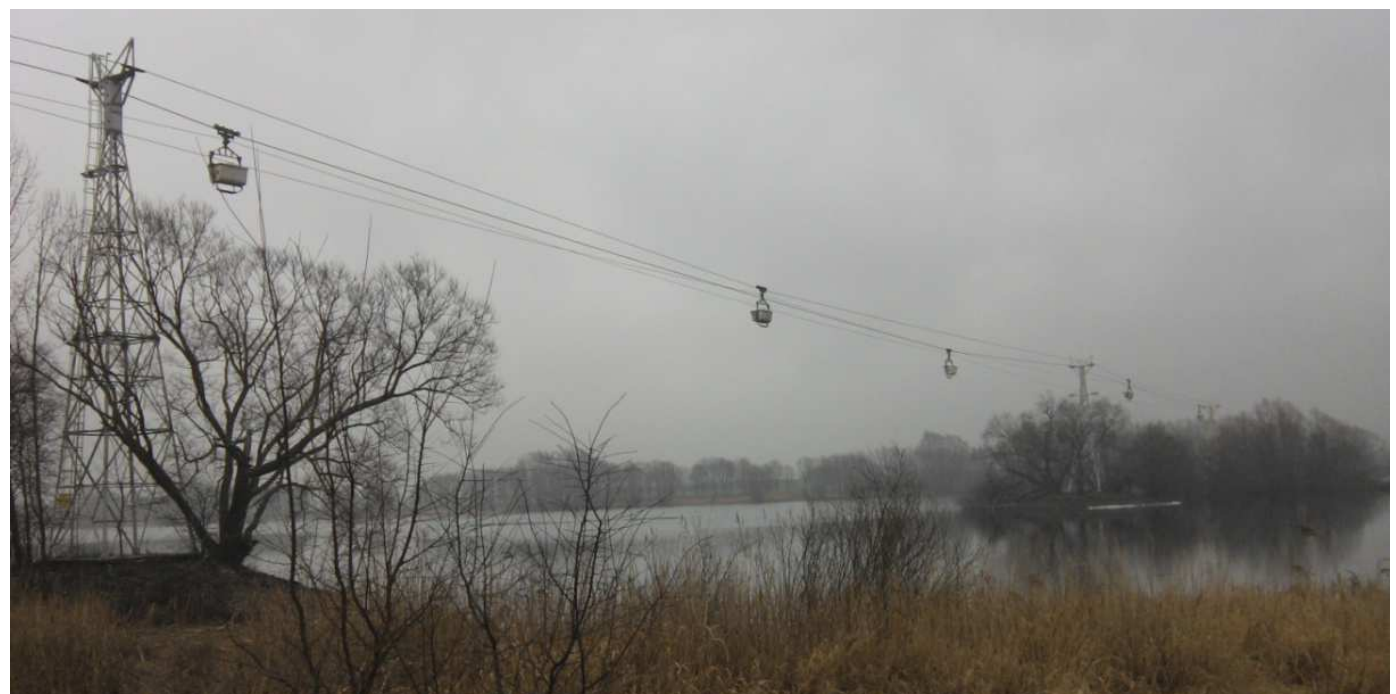

7. Ropeway route - at the Pakoski Lake 


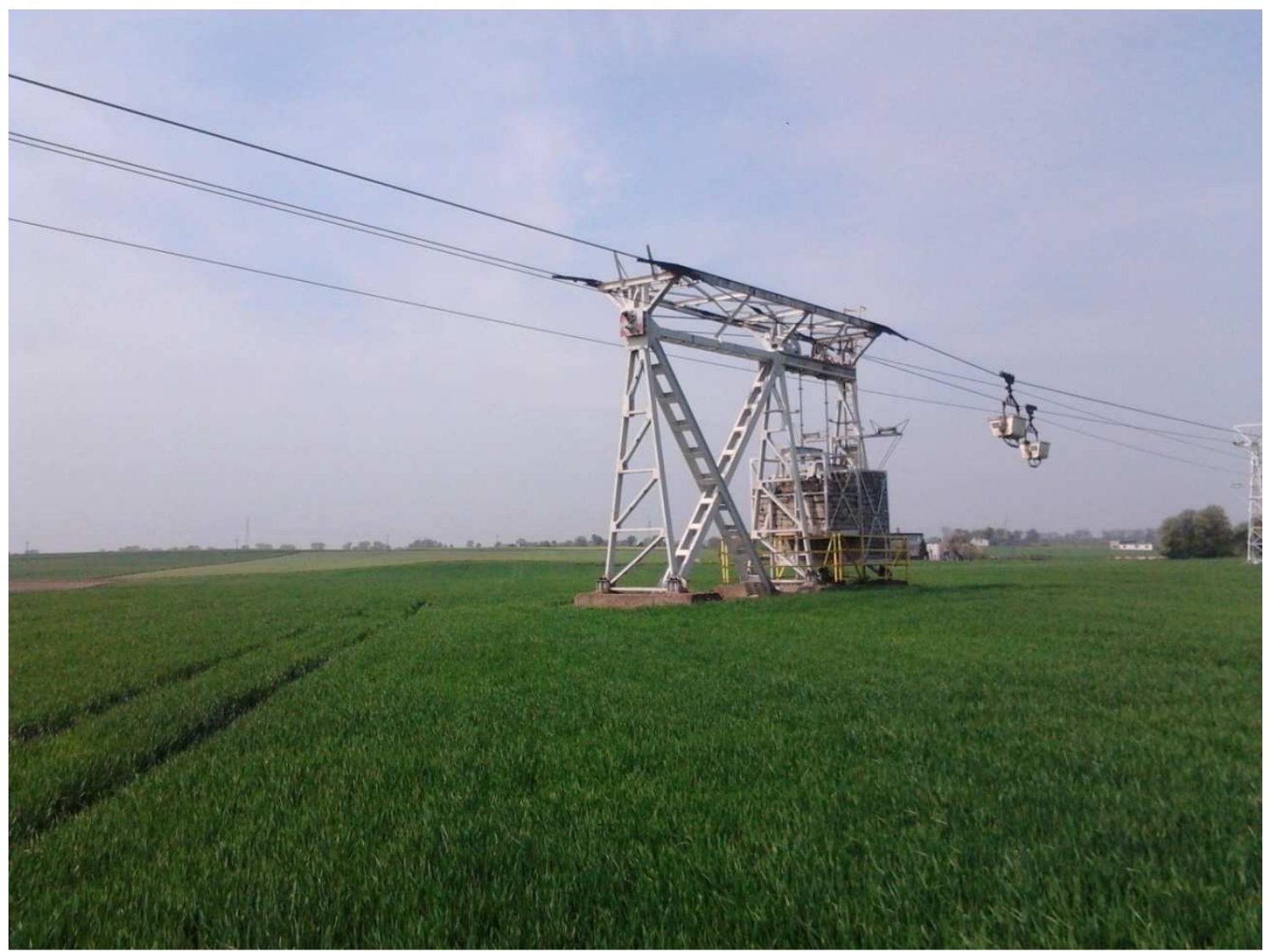

8. Station tensioning ropes carrying adjacent ropeway sections.

Why was bicable system used?

- The basic premises for the use of the double helical system were in this case the following conditions:

- terrain obstacle in the form of a lake - necessary long distances between the supports,

- energy costs - the bicable ropeway has an advantage,

- for this route only the bicable system gives you the possibility to use one drive.

However, there are several aspects that speak against this solution. They can be counted as i.a.:

- breaking down of the ropeway track and the need to disengage vehicles (in this case the bicable system causes more complications,

- the long route of the ropeway makes it necessary to divide the sections of the ropes,

- in the case of bicable ropeway, the end stations are more complex.

The above conditions indicate that in this case it is a better solution would be a monocable ropeway composed of three sections. However, this would entail the complete reconstruction of Janikowo-Piechcin, which in the current conditions of operation of the soda plants in Janikowo (part of Soda Polska CIECH S.A.) is not possible. 


\section{Summary}

Analysis of construction solutions of bicabe ropeways operating in Poland, it can be stated that these are ropeways where in general the bicable system has proved itself in practice. Of course, in some cases, considering the modern solutions of monocable ropeways, the bicable system loses its advantage (e.g. the Janikowo-Piechcin freight ropeway).It seems that bicable ropeways will continue to be built on the basis of their undeniable advantages where these advantages can be maximized. However, the leader of the ropeway will, of course, remain the "in the hands" of the overhead ropeway.

\section{Source materials}

[1] Doppelmayr A., „Warunki projektowania napowietrznych kolei jednolinowych o ruchu okrężnym", opracowanie wydania polskiego M. Wójcik, T. Rokita, Wyd. KTL AGH, Kraków 1997.

[2] Dyrektywa Unii Europejskiej i Rady Nr 2000/9/WE odnosząca sie do urządzeń kolei linowych przeznaczonych do przewozu osób. Dz. U. UE 2005/C 230/C, marzec 2000.

[3] Gric R., Nejez J.: Haben Zweiseil - Umlaufbahnen eine Zukunft?, ISR (Internationale Seilbahn - Rundschau) w 2015 r.

[4] Olszyna G., Rokita T., Tytko A., Wójcik M.: Role of cable transport in the management and development of the mountain areas, Geomatics, Landmanagement and Landscape ; no. 4, 2013

[5] Olszyna G., Rokita T., Wójcik M.: Opracowanie koncepcji modernizacji kolei linowej towarowej na odcinku Nr 5 Janikowo-Piechcin wraz z częścią projektową. Etap I i II, AGH Akademia Górniczo - Hutnicza, Katedra Transportu Linowego, Październik 2015, Materiały niepublikowane.

[6] PN-EN 12929-1:2006- „Wymagania bezpieczeństwa dla osobowych kolei linowych” Wymagania ogólne Część 1: Wymagania dotyczące wszystkich urządzeń. PKN, Warszawa 2006.

[7] PN-EN 12929-2: 2006:Wymagania bezpieczeństwa dla osobowych kolei linowych Wymagania ogólne Część 2: Dodatkowe wymagania dla dwulinowych napowietrznych kolei linowych wahadłowych bez hamulców w pojazdach. PKN, Warszawa 2006.

[8] PN-EN 12930:2006: Wymagania bezpieczeństwa dla osobowych kolei linowychobliczenia. PKN, Warszawa 2006.

[9] Rokita T.: Modernizacja kolei linowej towarowej Janikowo-Piechcin Logistyka nr 4, 2015

[10] Rozporządzenie Ministra Infrastruktury z dnia 11 grudnia 2003 r. w sprawie zasadniczych wymagań dla kolei linowych przeznaczonych do przewozu osób, Dz. U. z $2004 \mathrm{Nr}$ 15, poz. 130.

[11] Rozporządzenie Ministra Transportu z dnia 1 czerwca 2006 r. w sprawie warunków technicznych dozoru technicznego w zakresie projektowania, wytwarzania, eksploatacji, naprawy i modernizacji urządzeń transportu linowego Dz. U. Nr 106, poz. 717.

[12] Schneigert Z.: Koleje linowe napowietrzne, Wydawnictwo Komunikacyjne 1957. 